Chapter 2

\title{
The Development and Regulation of Soybean Nodules
}

\author{
Brett James Ferguson \\ Additional information is available at the end of the chapter \\ http://dx.doi.org/10. 5772/52573
}

\section{Introduction}

\subsection{Legumes: Environmentally and agronomically important plant species}

Legumes represent the third largest family of angiosperms, with $>18,000$ species worldwide (Leguminosae or Fabaceae). Due to their high nutritional value, they have been cultivated by many cultures for use in agriculture. Indeed, legumes currently represent some of the most important food, feed and fuel crops grown around the world, second only to cereals. They have a global-production value of $>\$ 200$ billion per year and are cultivated on $12-15 \%$ of the world's available, arable land (Graham and Vance 2003; Peoples et al., 2009; Jensen et al., 2012). Collectively, 247 million tons of legumes are produced each year, and represent $>$ $25 \%$ of the world's primary crop production (Graham and Vance 2003; European Association for Grain Legume Research 2009). Some key legume crop species include: soybean, bean, pea, chickpea, cowpea, pigionpea and alfalfa.

Legumes play a significant role in both agriculture and in natural ecosystems by having a unique influence on the nitrogen cycle. They do so via a highly-specialized symbiotic relationship with soil bacteria commonly called rhizobia. Via a sophisticated signaling exchange, the bacteria infect the plant root and induce the formation of novel organs, termed nodules (Ferguson et al., 2010). The nodule is colonized by the bacteria and provides them with an ideal habitat to convert or 'fix' atmospheric di-nitrogen into other nitrogen-based compounds, such as ammonia, which can be used by the plant. This benefits the plant directly, as nitrogen is essential for growth. It also benefits the rhizosphere as the soil nitrogen content is replenished once the plant dies and subsequently decomposes (referred to as 'green manure'). As a result, legumes are often used in crop rotations in agriculture. In addi- 
tion, some legumes are being exploited as a source of sustainable biofuel. Species such as soybean, and the tree legume Pongamia pinnata, offer the most promise due to their high seed oil content (Scott et al., 2008).

\section{Nitrogen fertilizer: An unsustainable reliance in modern agriculture}

Current agriculture practices are heavily reliant on nitrogen-based fertilizers to achieve high yields (Peoples et al., 2009; Jensen et al., 2012). Indeed, it is estimated that half of the world's population is fed as a direct result of nitrogen fertilizer use (Erisman et al., 2008). Although this approach works well to maximize crop production, it is a very risky dependence that is not sustainable, and is inefficient, expensive, and often pollutes. Hence, there are a number of very sound reasons to lessen these nitrogen inputs and alleviate the current reliance.

The production of industrial nitrogen fertilizers requires a great deal of fossil fuel, involving what is known as the Haber-Bosch process. Once manufactured, additional fossil fuel is needed to transport the fertilizer to its place of sale, and then even more fossil fuel is needed to apply it in the field. Collectively, this accounts for a staggering $50 \%$ of fossil fuel use in modern agriculture and $5 \%$ of the world's annual consumption of natural gas (Crutzen et al., 2007; Canfield et al., 2010). As a direct result, the purchase and application of nitrogen fertilizer can be quite expensive, preventing many farmers in developing regions of the world from being able to use it. Moreover, as the cost of fossil fuel continues to rise, so too does the cost of nitrogen fertilizer. This can considerably cut into farmer profits and often leads to costs being passed on to the consumer.

In addition to the monetary costs associated with nitrogen fertilizer use, there are often considerable environmental costs. It is reported that industrial manipulation of the nitrogen cycle has already exceeded safe boundaries for global environmental change (Rockstrøm et al., 2009; Canfield et al., 2010; Charpentier and Oldroyd 2010; Beatty and Good 2011). Due to the combustion of fossil fuel, the production and application of nitrogen fertilizer results in large quantities of carbon dioxide $\left(\mathrm{CO}_{2}\right)$ being released into the atmosphere. This contributes to the greenhouse effect, as does the release of nitrous oxide $\left(\mathrm{N}_{2} \mathrm{O}\right)$, which is produced during the decomposition of nitrogen fertilizer in the soil and is estimated to be 292 times more active as a greenhouse gas than $\mathrm{CO}_{2}$ (Crutzen et al., 2007).

Each year $>100$ million tonnes of nitrogen are applied to crops worldwide (Glass 2003). This excessive use of nitrogen reduces the levels of trace nutrients in the soil and increases soil acidity. Moreover, the application of nitrogen-based fertilizers is a largely inefficient process, with as much as $30-50 \%$ lost to leaching. This nitrogen run-off can cause significant environmental damage, including the eutrophication of waterways resulting from associated algal blooms, etc. (Vance 2001). Recent reports indicate that the cost to fix this environmental damage will significantly outweigh the economic benefit gained from nitrogen fertilizer use (Sutton et al., 2011).

The excess runoff from nitrogen fertilizer can also contaminate drinking water. High levels of nitrogen in drinking water can lead to methemoglobinaemia, commonly referred to as 
Blue-baby syndrome because of the blue-grey skin colour displayed by affected infants (Murphy 1991; Knobeloch et al., 2000). Blue-baby syndrome is potentially fatal and occurs when the hemoglobin of an infant's red blood cells is oxidized to methemoglobin, which is unable to properly transport oxygen.

\section{Biological nitrogen fixation: A sound alternative to nitrogen fertilizer}

Attempts to reduce the use of nitrogen fertilizers need to incorporate responsible, cost effective and environmentally sound options; an improved use of legumes and an increased understanding of legume nodulation represent such options. Indeed, this symbiotic relationship between legumes and rhizobia represents the most important nitrogen-fixation association in the world, with an annual production of approximately 200 million tons of nitrogen (Peoples et al., 2009; Jensen et al., 2012). Optimising this symbiosis can increase crop yields and enhance soil fertility, whilst reducing the negative monetary costs and environmental impacts associated with nitrogen fertilizer use (Hirel et al., 2007; Peoples et al., 2009; Canfield et al., 2010). Hence, increasing our use of legume crops and identifying critical factors required to control nodulation are seen as pivotal steps towards reducing our reliance on nitrogen fertilizers and improving agricultural sustainability (e. g. , Giller and Cadisch 1995; Vance 2001; Peoples et al., 2009; Rockstrøm et al., 2009; Canfield et al., 2010; Jensen et al., 2012).

Soybean alone is estimated to produce up to $200 \mathrm{~kg} \mathrm{~N} \mathrm{ha}^{-1}$ in aboveground biomass in a single growing season. Of the soybean nitrogen content, 58-68\% is estimated to be derived from symbiotic nitrogen fixation (Salvagiotti et al., 2008; Peoples et al., 2009; Jensen et al., 2012). Following harvesting, the remaining portions of the plant, including roots and nodules which represent $30-60 \%$ of the nitrogen content, are left to replenish the nitrogen content of the surrounding soil (Mahieu et al., 2007; McNeill and Fillery 2008).

\section{Legume nodules: The perfect environment for rhizobia nitrogen fixation}

Nodulation is a complex process orchestrated by a multitude of bacteria and plant signals (reviewed in Ferguson and Mathesius 2003; Ferguson et al., 2010). The process is initiated by plant roots secreting flavonoid molecules into the soil. This attracts compatible rhizobia and concomitantly stimulates them to synthesize a highly specific signal molecule called Nod factor. The rhizobia strain that is compatible with soybean is Bradyrhizobium japonicum. The plant perceives Nod factor via LysM receptors on the root. In soybean, these receptors are called GmNFR1 and GmNFR5 (Indrasumunar et al., 2010, 2011). Nod factor perception triggers a subsequent signaling cascade that is required for proper nodule establishment. The known legume and rhizobia genes/signals that are involved in this signaling cascade have recently been thoroughly reviewed in Ferguson (2012). 
The presence of the rhizobia together with their Nod factor signal molecule initiates the nodulation infection process. Root hair penetration is the most common form of rhizobia invasion. The bacteria attach to emerging root hairs, which begin to deform and eventually encapsulate some of the bacteria, which are continuously dividing (Callaham and Torrey 1981; Turgeon and Bauer 1985). This process happens in as little as $6-8 \mathrm{~h}$ post-inoculation (Yao and Vincent 1969; Bhuvaneswari et al., 1981; Bhuvaneswari and Solheim 1985; Turgeon and Bauer 1982, 1985). Specialized structures, called infection threads, begin to form and provide a passage way for the bacteria to enter the root (reviewed by Gage 2004). These infection threads are predominately comprised of plant cell wall components and they permit the bacteria to continue proliferating within the host plant.

As the process of rhizobia infection occurs, cortical cells in the root begin to divide and eventually give rise to the nodule primordium (Calvert et al., 1984; Mathews et al., 1989). The position of the nodule primordium is typically adjacent to the radial cells of the xylem, and away from the phloem. This positioning is thought to be largely dependent on plant hormone levels, namely gradients of the gaseous hormone, ethylene (Heidstra et al., 1997; Gresshoff et al., 2009; Lohar et al., 2009). Additional tissues, including vascular tissues and central nodule tissues that are composed of both invaded and non-invaded cells, also develop to form the nodule structure (Newcomb et al., 1979; Calvert et al., 1984; Ferguson and Reid 2005).

Infection threads initiating in the root hair eventually grow and extend towards the dividing nodule primordium located in the root cortex. Once there, rhizobia located at the tip of the infection threads are released into an infection droplet that separates and is released into the cytoplasm of the host cell. Within the cytoplasm, the rhizobia are encapsulated by a specialized plant-derived membrane, known as the peribacteroid membrane, making what is commonly referred to as the symbiosome (Udvardi and Day 1997).

Ultimately, the dividing bacteria differentiate into what are known as bacteroids, which are highly specialized and whose main purpose is to fix atmospheric di-nitrogen gas. Inside the mature nodule, the bacteroids use a nitrogenase enzyme complex to fix the di-nitrogen into forms of nitrogen that the plant can use, such as ammonia. The ammonia, which is toxic to the plant, is then quickly converted into compounds such as glutamate or ureides that are non-toxic and are safely transported throughout the plant. Legume nodules provide the ideal setting for this process as they establish a peripheral oxygen barrier, via physical and metabolic barriers, to create a low-oxygen environment that is essential for nitrogenase activity to occur.

The nodules formed on the roots of soybean plants are referred to as 'determinate' nodules. They are spherical and lack a persistent meristem, unlike indeterminate nodule structures that can form on other legume species, particularly those from temperate growing regions (Ferguson et al., 2010). The life-span of a soybean nodule is typically a few weeks, after which they senesce and are replaced by new nodule structures developing on the growing root system. Following nodule senescence, the bacteroids can re-differentiate and become new inoculum for the soil (Gresshoff and Rolfe 1978). 


\section{Autoregulation of nodulation: Too much of a good thing can be bad}

A number of genes that are required for proper nodule formation have been elucidated (reviewed in Caetano-Anollés and Gresshoff 1991; Ferguson et al., 2010; Ferguson, 2012). The loss of any of these genes typically results in a reduced, or a complete lack of, nodule development. In addition to these positive regulators of nodule formation, there are also a number of external and internal factors that act as negative regulators of nodulation. Mutants unable to synthesise or perceive these factors exhibit increased nodule numbers, often referred to as a hyper- or super-nodulation phenotype (Figure 1). Many of these factors function in the Autoregulation of Nodulation (AON) pathway, which is a mechanism used by the host plant to regulate its nodule numbers (reviewed in Reid et al., 2011a). Indeed, less than $10 \%$ of all rhizobia infection events result in the establishment of a fully functional nodule, largely due to AON. By controlling nodule development in this way, the host plant can balance its need to acquire nitrogen against its ability to expend energy establishing and maintaining nodules. Supernodulating plants lacking AON are typically developmentallystunted (when inoculated with a compatible rhizobia strain) and yield poorly as a result of this balance being disrupted (Figure 2).

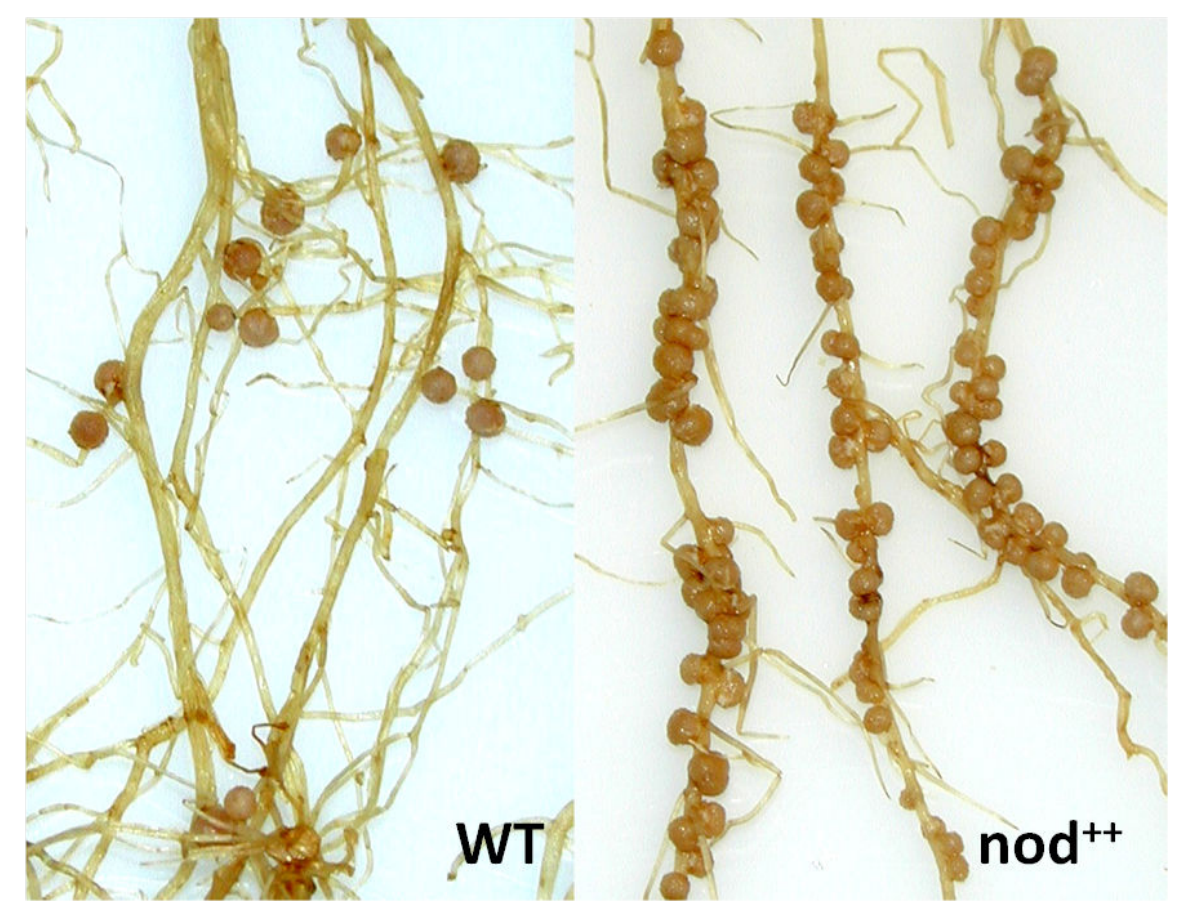

Figure 1. Roots of wild-type (WT) and supernodulating mutant (nod ${ }^{++}$) soybean plants exhibiting mature nodule structures as a result of a symbiotic interaction with Bradyrhizobium japonicum. 


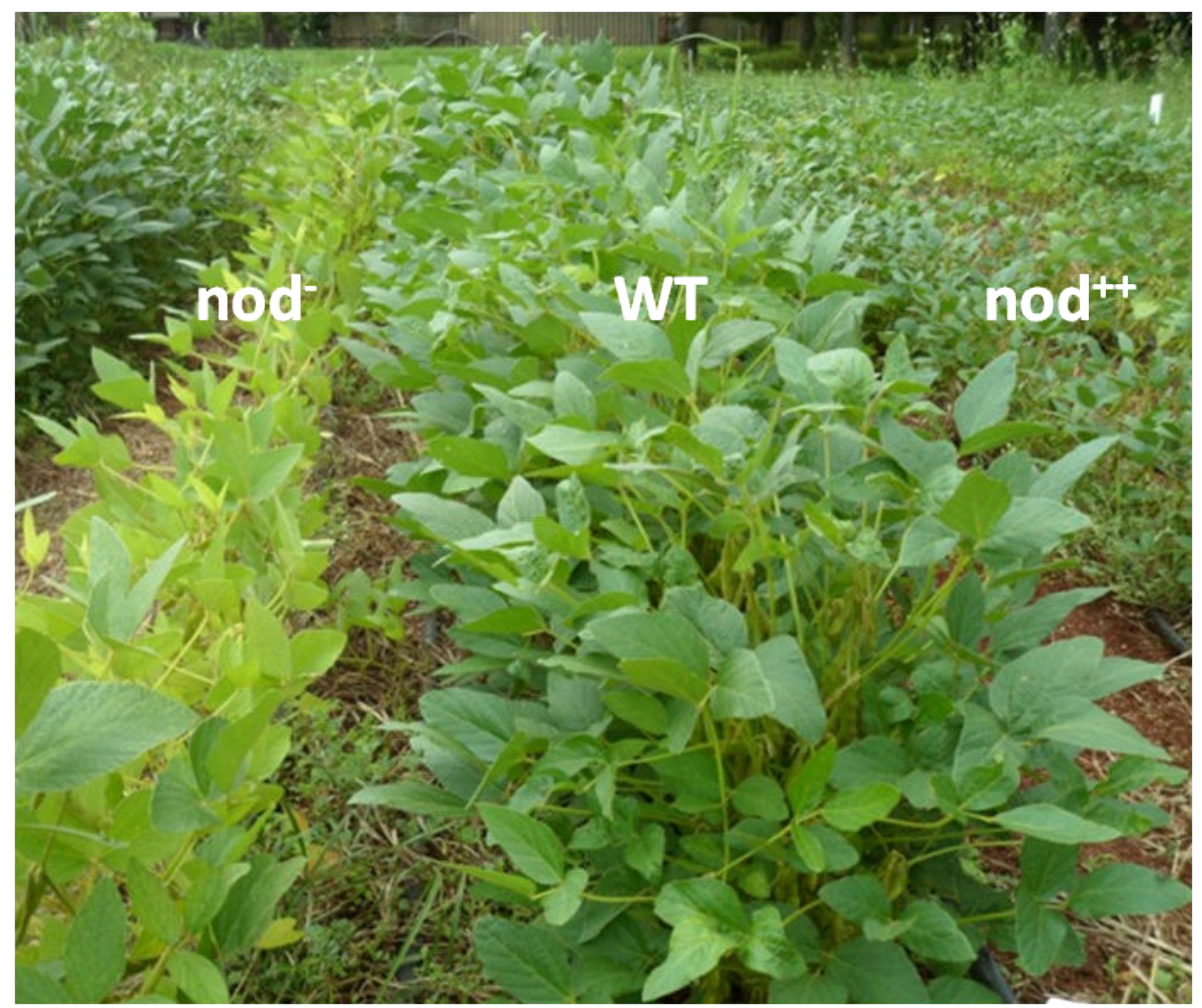

Figure 2. Soybean plants growing in a field in Toowoomba, Queensland, Australia. Mutants unable to form nodules (nod) $)$ are stunted and pale compared with wild-type (WT) plants due to their inability to establish a symbiotic interaction with nitrogen-fixing Bradyrhizobium japonicum. Supernodulating mutants $\left(\right.$ nod $\left.^{++}\right)$are significantly stunted in stature as a result of investing too much energy into forming nodule structures.

The AON pathway involves long-distance root-shoot signaling initiated during nodule development by the synthesis of a root-derived signal (Gresshoff and Delves, 1986; Delves et al, 1986; Reid et al., 2011a). Recent work has indicated that this signal is likely a CLV3/ESRrelated (CLE) peptide(s) hormone (Okamoto et al., 2009; Mortier et al., 2010; Reid et al., 2011b; Lim et al., 2011). In soybean, these CLE peptides are called Rhizobia Induced CLE1 (RIC1) and RIC2 (Reid et al 2011b; Lim et al., 2011). Grafting and over-expression experiments have shown that these signals travel to the shoot (Delves et al., 1986; Reid et al., 2011b), likely via the xylem, where they, or a product of their action, are perceived by a LRR receptor kinase, called the Nodulation Autoregulation Receptor Kinase (NARK) in soybean (e. g. , Searle et al., 2003). NARK may act in a complex with other receptors, such as CLAVATA2 and KLAVIER (Miyazawa et al., 2010; Krusell et al., 2011). This perception results in the production of a novel Shoot-Derived Inhibitor (SDI). The SDI signal subsequently travels from the shoot back down to the roots, likely via the phloem, where it acts to inhibit further nodulation events (Reid et al 2011a). It has recently been established in soybean that SDI is 
small ( $<1 \mathrm{kDa})$, Nod factor- and NARK-dependent, heat stable, and is unlikely to be an RNA or a protein (Lin et al., 2010, 2011a). Recent work using soybean has also identified a number of novel components that may interact with NARK directly, or that may function downstream of NARK to regulate the AON process. These include genes identified using site-directed mutagenesis that encode Kinase-Associated Protein Phosphatases, called GmKAPP1 and GmKAPP2 (Miyahara et al., 2008), and genes identified using complete transcriptome analyses (RNAseq), such as the putative Ubiquitin Fusion Degradation protein, GmUFD1a (Reid et al., 2012).

Additional genes and factors also regulate nodule numbers. Root-specific genes in pea (PsNOD3; Postma et al., 1988) and L. Japonicas (LjRDH1, Ishikawa et al., 2008; LjTML, Magori et al., 2009) may have a role in the biosynthesis or translocation of RIC1 and RIC2, or in the perception of SDI. However, the identity of these genes is not yet known. Loss of function of LjASTRAY, which encodes a bZIP transcription factor (Nishimura et al., 2002), or MtEFD, which encodes an ERF transcription factor (Vernié et al., 2008), also results in increased nodule numbers. Whether these genes function in the AON pathway remains to be determined.

Ethylene and nitrate are also known to inhibit nodule development (Carroll et al., 1985; Lorteau et al., 2001; Ferguson et al., 2005 a,b; Ferguson et al., 2011). Mutations to ethylene sensitivity or response genes, such as LjETR1 and LjEIN2/MtEIN2, result in increased nodule formation (Penmetsa et al., 2008; Gresshoff et al., 2009; Lohar et al., 2009). Interestingly, an additional CLE peptide identified in soybean that negatively regulates nodule development, called Nitrogen-Induced CLE1 (NIC1) is highly similar to RIC1 and RIC2, but is induced by nitrate, not rhizobia (Reid et al., 2011b). Both the RICs and NIC1 appear to be perceived by GmNARK, only the nitrate-induced CLE exhibits little-to-no mobility and is perceived in the root, whereas the rhizobia-induced CLE undergoes long distance transport and is perceived in the shoot.

\section{Soybean: A model species for legume research}

Soybean has been the subject of a great deal of research in an effort to identify unique traits and to isolate superior cultivars offering improved growth and yields (Gresshoff 2012). It also represents an excellent model species for legumes in general (Ferguson and Gresshoff 2009), with outcomes frequently extrapolated to the other important food and feed legume crops, such as bean, pea, chickpea, faba bean, lentil, peanut, clover and lucerne (e.g. , Rispail et al., 2010).

Soybean represents one of the best characterized legumes species, both physiologically and biochemically. It grows quickly, is high yielding, and has a size and stature that are well suited for most field and laboratory studies (Figure 3). Its relatively large size enables the harvest of large quantities of tissues and it is ideal for studies involving grafting (e. g. , Delves et al., 1986; Reid et al., 2011b), xylem sap analyses (e. g. , Djordjevic et al., 2007), Agrobacterium rhizogenes-mediated transformation for gene over-expression and RNA interference (e. g. , Kereszt et al., 2007; Reid et al., 2011b; Lin et al., 2011b) and Virus-Induced Gene 
Silencing (VIGS) for functional genomics approaches (e.g. , Zhang and Ghabrial, 2006). Furthermore, soybean has a large germplasm, including vast mutant (Figure 2; e. g. , Carroll et al., 1985; Bolon et al., 2011) and TILLING populations (e. g. , Cooper et al., 2008; Batley et al., 2012).
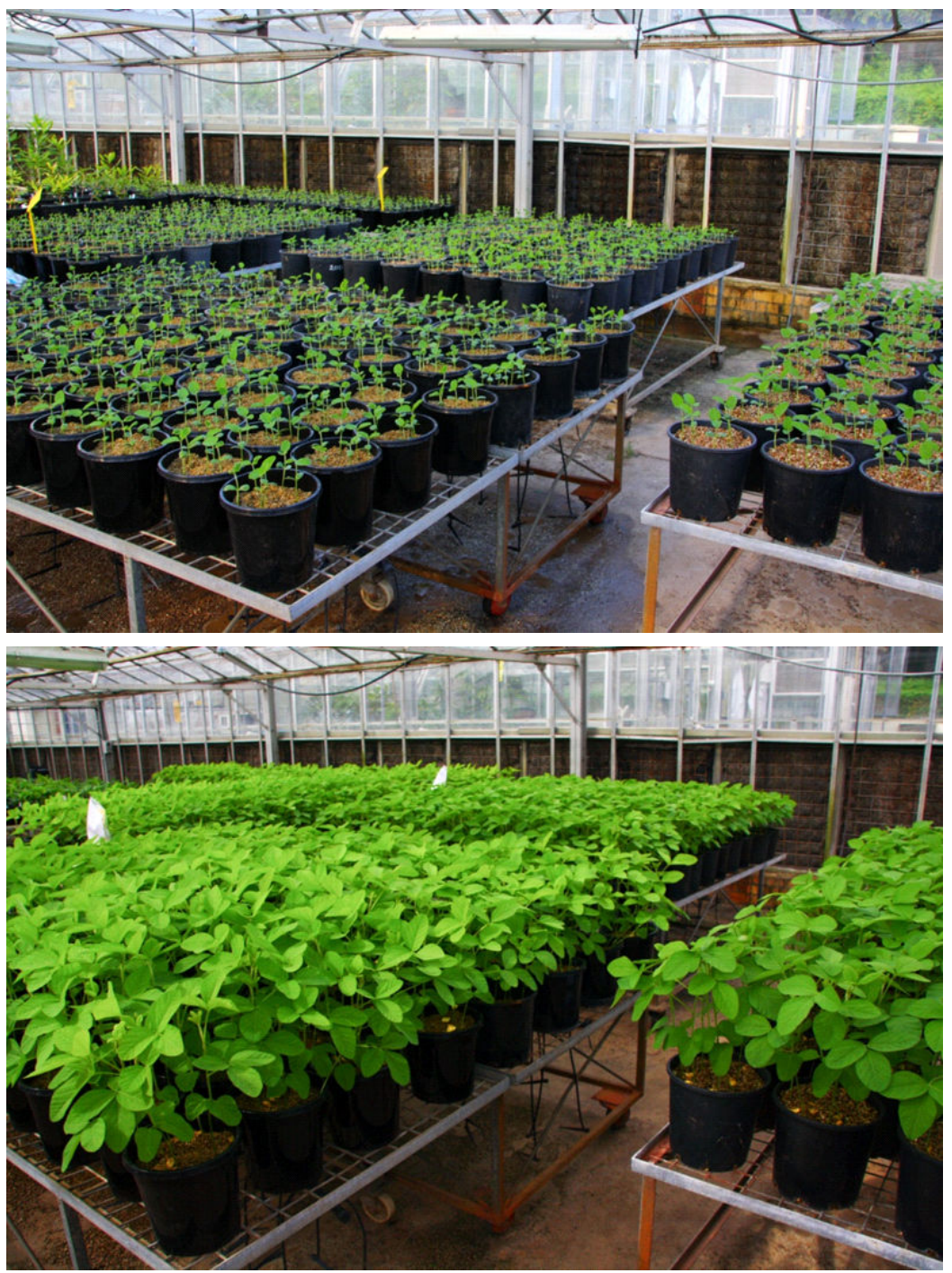

Figure 3. Glasshouse grown soybean plants 1 and 3 weeks after germination. The fast, uniform growth of soybean, together with the availability of its genome sequence and its amenability to most physiological, molecular and biochemical analyses makes it an ideal model species for legume research. 
Recently, the soybean genome was sequenced (Schmutz et al., 2010) and complete transcriptome analyses have been performed, including the generation of transcriptome atlases ( $\mathrm{Li}$ bault et al., 2010a,b; Severin et al., 2010; Reid et al., 2012; Hayashi et al., 2012). Together, these resources provide an efficient non-targeted tool to identify new genes and patterns of gene expression. Analyses between the genome of soybean and those available for other legumes species, including M. truncatula, L. japonicus, pigionpea and bean, also provide an excellent opportunity for comparative legume genomics (Cannon et al., 2009).

Understanding the genes and genomes of legumes will help to establish elite cultivars that benefit sustainable farming practices. Integrating central regulators of nodulation is essential for such targeted legume crop improvement. Indeed, outcomes derived via soybean research could help to underpin future advances in managing the legume-rhizobia symbiosis (e. g. , Rispail et al., 2010). This could lead to improved nitrogen use efficiency and reduced nitrogen-fertilizer inputs, thus helping to reduce the monetary and environmental costs associated with nitrogen-fertilizer use.

\section{Conclusions and future perspectives}

The processes of nodulation and nitrogen fixation have long been recognized for their agricultural benefits and ability to improve soil-health. Recent work identifying the genes and signals involved in nodule formation and AON have significantly enhanced our understanding of the processes and could provide targets for plant breeding and engineering programs aiming to develop legume, and perhaps even non-legume, varieties with an improved ability to acquire nitrogen.

\section{Abbreviations}

AON (Autoregulation Of Nodulation);

CLE (CLV3/ESR-related peptide);

NARK (Nodulation Autoregulation Receptor Kinase);

NIC (Nitrogen-Induced CLE peptide);

Nod Factor (Nodulation Factor);

RIC (Rhizobia-Induced CLE peptide);

RNAseq (RNA sequencing);

SDI (Shoot Derived Inhibitor) 


\section{Acknowledgements}

Thanks to Prof. Peter M. Gresshoff for his helpful discussions and kind advice. The Australian Research Council, The University of Queensland and the Centre of Excellence for Integrative Legume Research (CEO348212) are thanked for financial assistance.

\section{Author details}

Brett James Ferguson

Centre of Excellence for Integrative Legume Research, School of Agriculture \& Food Sciences, The University of Queensland, St Lucia, Brisbane, Australia

\section{References}

[1] Batley J, Liu S, Mirzaei S, El-Mellouki T, Ferguson BJ, Gresshoff PM, Meksem K (2012) TILLING in soybean reveals contrasting mutant phenotypes of LRR-receptor kinase genes GmNARK and GmCLAVATA1A. BMC Genomics, submitted.

[2] Beatty PH, Good AG (2011) Future prospects for cereals that fix nitrogen. Science 333: 416-417.

[3] Bolon Y-T, Haun W, Xu W, David Grant, Stacey MG, Nelson RT, Gerhardt DJ, Jeddeloh JA, Stacey G, Muehlbauer GJ, Orf JH, Naeve S, Stupar RM, Vance CP (2011) Phenotypic and genomic analyses of a fast neutron mutant population resource in soybean. Plant Physiology 156: 240-253.

[4] Bhuvaneswari T V, Bhagwat AA, Bauer WD (1981) Transient susceptibility of root cells in four common legumes to nodulation by rhizobia. Plant Physiology 68: 1144-1149.

[5] Bhuvaneswari TV, Solheim B (1985) Root hair deformation in the white clover/Rhizobium trifolii symbiosis. PhysiologiaPlantarum 63: 25-34.

[6] Caetano-AnollésG, Gresshoff PM (1991) Plant genetic control of nodulation. Annual Review of Microbiology45: 345-382.

[7] Cannon SB, May GD, Jackson SA (2009) Three sequenced legume genomes and many crop species: rich opportunities for translational genomics. Plant Physiology 151: 970-977.

[8] Callaham DA, Torrey JG (1981) The structural basis for infection of root hairs of Trifolium repens by Rhizobium. Canadian Journal of Botany 59: 1647- 1664. 
[9] Calvert, H.E., Pence, M.K., Pierce, M., Malik, N.S.A. and Bauer, W.D. (1984) Anatomical analysis of the development and distribution of Rhizobium infections in soybean roots. Canadian Journal of Botany 62: 2375-2384.

[10] Canfield DE, Glazer AN, Falkowski PG (2010) The evolution and future of earth's nitrogen cycle. Science 330: 192-196.

[11] Charpentier M, Oldroyd G (2010) How close are we to nitrogen-fixing cereals? Current Opinion in Plant Biology 13: 556-564.

[12] Carroll BJ, McNeil DL, Gresshoff PM (1985) Isolation and properties of soybean [Glycine $\max$ (L.) Merr.] mutants that nodulate in the presence of high nitrate concentrations. Proceeding of the National Academy of Science USA 82: 4162-4166.

[13] Cooper JL, Till BJ, Laport RG, Darlow MC, Kleffner JM, Jamai A, El-Mellouki T, Liu S, Ritchie R, Nielsen N, Bilyeu KD, Meksem K, Comai L, Henikoff S(2008) TILLING to detect induced mutations in soybean. BMC Plant Biology 8: 9.

[14] Crutzen P, Mosier AR, Smith KA, Winiwarter W (2007) N2O release from agro-fuel production negates global warming reduction by replacing fossil fuels. Atmos Chem Phys Discussions 7: 11191-11205.

[15] Delves, A.C., Mathews, A., Day, D.A., Carter, A.S., Carroll, B.J. and Gresshoff, P.M. (1986) Regulation of the soybean-Rhizobium nodule symbiosis by shoot and root factors. Plant Physiology 82: 588-590.

[16] Djordjevic MA, Oakes M, Li D, Hwang CH, Hocart CH, Gresshoff PM (2007) The Glycine max xylem sap and apoplast proteome. Journal of Proteome Research 6: 3771-3779.

[17] European Association for Grain Legume Research (www.grainlegumes.com), accessed January 2009.

[18] Erisman JW, Sutton MA, Galloway J, Klimont Z, Winiwarter W (2008) How a century of ammonia synthesis changed the world. Nature Geosciences 1: 636-639.

[19] Ferguson, B.J. (2012) Rhizobia and legume nodulation genes. In: Brenner's Online Encyclopedia of Genetics, 2nd edn (Maloy, S. and Hughes, K., eds), Oxford, UK: Elsevier/ Academic Press, In press.

[20] Ferguson, B.J., Foo, E., Ross, J.J. and Reid, J.B. (2011) Relationship between gibberellin, ethylene and nodulation in Pisum sativum. New Phytologist 189: 829-842.

[21] Ferguson, B.J. and Gresshoff, P.M. (2009) Soybean as a model legume. Grain Legumes: 53: 7 .

[22] Ferguson, B.J., Indrasumunar, A., Hayashi, S., Lin, M-H., Lin, Y-H., Reid, D.E. and Gresshoff, P.M. (2010) Molecular analysis of legume nodule development and autoregulation. Journal of Integrative Plant Biology 52: 61-76. 
[23] Ferguson, B.J. and Mathesius, U. (2003) Signaling interactions during nodule development. Journal of Plant Growth Regulation 22: 47-72.

[24] Ferguson BJ, Reid JB (2005) cochleata: getting to the root of legume nodules. Plant Cell Physiology46: 1583-1589.

[25] Ferguson, B.J., Ross, J.J. and Reid, J.B. (2005) Nodulation phenotypes of gibberellin and brassinosteroid mutants of pea. Plant Physiology 138: 2396-2405.

[26] Ferguson BJ, Wiebe EM, Emery RJN, Guinel FC (2005b) Cytokinin accumulation and an altered ethylene response mediate the pleiotropic phenotype of the pea nodulation mutant R50 (sym16). Canadian Journal of Botany83: 989-1000.

[27] Food and Agriculture Organization of the United Nations (www.faostat.fao.org), accessed January 2010.

[28] Gage DJ (2004) Infection and invasion of roots by symbiotic, nitrogenfixing rhizobia during nodulation of temperate legumes.Microbiol.Mol. Biol.Rev. 68: 280-300.

[29] Giller KE, Cadisch G (1995) Future benefits from biological nitrogen fixation: An ecological approach to agriculture. Plant and Soil 174: 255-277.

[30] Glass A (2003) Nitrogen use efficiency of crop plants: physiological constraints upon nitrogen absorption. Critical Reviews in Plant Sciences 22: 453-470.

[31] Graham PH, Vance CP (2003) Legumes: Importance and constraints to greater use. Plant Physiology131: 872-877.

[32] Gresshoff, P.M. (2012) Glycine max (soybean). In: Brenner's Online Encyclopedia of Genetics, 2nd edn (Maloy, S. and Hughes, K., eds), Oxford, UK: Elsevier/Academic Press, In press.

[33] Gresshoff PM, Delves AC (1986) Plant genetic approaches to symbiotic nodulation and nitrogen fixation in legumes. In: Blonstein AD, King PJ, eds. Plant Gene Research III. A Genetical Approach to Plant Biochemistry. Springer Verlag, Wien. pp. 159-206.

[34] Gresshoff PM, Lohar D, Chan PK, Biswas B, Jiang Q, Reid D, Ferguson B, Stacey G (2009) Genetic analysis of ethylene regulation of legume nodulation. Plant Signalling and Behaviour 4: 818-823.

[35] Gresshoff PM, Rolfe, BG (1978) Viability of Rhizobium bacteroids isolated from soybean nodule protoplasts. Planta 142: 329-333.

[36] Hayashi S, Reid DE, Lorenc M, Stiller J, Edwards D, Gresshoff PM, Ferguson BJ (2012) Transient Nod-factor dependent gene expression in the nodulation competent zone of soybean (Glycine max L. Merr.) roots. Plant Biotechnology Journal, doi: 10.1111/j.1467-7652.2012.00729.x

[37] Heidstra R, Yang WC, Yalcin Y, Peck S, Emons AM, Van Kammen A, Bisseling T (1997) Ethylene provides positional information on cortical cell division but is not in- 
volved in Nod factor induced root hair tip growth in Rhizobium-legume interaction. Development 124: 1781-1787.

[38] Hirel B, Le Gouis J, Ney B, Gallais A (2007) The challenge of improving nitrogen use efficiency in crop plants: towards a more central role for genetic variability and quantitative genetics within integrated approaches. Journal of Experimental Botany 58: 2369-2387.

[39] Indrasumunar, A., Kereszt, A., Searle, I., Miyagi, M., Li, D., Nguyen, C.D.T., Men, A., Carroll, B.J. and Gresshoff, P.M. (2010) Inactivation of duplicated Nod factor receptor 5 (NFR5) genes in recessive loss-of-function non-nodulation mutants of allotetraploid soybean (Glycine max L. Merr.). Plant Cell Physiology 51: 201-214.

[40] Indrasumunar, A., Searle, I., Lin, M-H., Kereszt, A., Men, A., Carroll, B.J. and Gresshoff, P.M. (2011) Nodulation factor receptor kinase 1a controls nodule organ number in soybean (Glycine max L. Merr.) The Plant Journal 65: 39-50.

[41] Jensen ES, Peoples MB, Boddey RM, Gresshoff PM, Hauggaard-Nielsen H, Alves BJR, Morrison MJ (2012) Legumes for mitigation of climate change and feedstock in a bio-based economy - A review. Agronomy for Sustainable Development 32: 329-364.

[42] Ishikawa K, Yokota K, Li YY, Wang Y, Liu CT, Suzuki S, Aono T, Oyaizu H (2008) Isolation of a novel root-determined hypernodulation mutant rdh1 of Lotus japonicus. Soil Science and Plant Nutrition54: 259-263.

[43] Kereszt, A., Li, D., Indrasumunar, A., Nguyen, C.D.T., Nontachaiyapoom, S., Kinkema, M., and Gresshoff, P.M. (2007).Agrobacterium rhizogenes-mediated transformation of soybean to study root biology. Nature Protocols 2: 948-952.

[44] Krusell L, Sato N, Fukuhara I, et al. 2011. The Clavata2 genes of pea and Lotus japonicus affect autoregulation of nodulation. The Plant Journal 65: 861-871.

[45] Lohar D, Stiller J, Kam J, Stacey G, Gresshoff PM (2009) Ethylene insensitivity conferred by a mutated Arabidopsis ethylene receptor gene alters nodulation in transgenic Lotus japonicus. Annals of Botany104: 277-285.

[46] Lorteau MA, Ferguson BJ, Guinel FC (2001) Effects of cytokinin on ethylene production and nodulation in pea (Pisumsativum) cv. Sparkle. Physiologia Plantarum 112: 421-428.

[47] Knobeloch L, Salna B, Hogan A, Postle J, Anderson H (2000)Blue babies and nitratecontaminated well water. Environmental Health Perspectives 108: 675-678.

[48] Libault. M., Farmer, A., Brechenmacher, L., Drnevich, J., Langley, R.J., Bilgin, D.D., Radwan, O., Neece, D.J., Clough, S.J., May, G.D. and Stacey, G.(2010a) Complete transcriptome of the soybean root hair cell, a single-cell model, and its alteration in response to Bradyrhizobium japonicum infection.Plant Physiology 152: 541-552.

[49] Libault, M., Farmer, A., Joshi, T., Takahashi, K., Langley, R.J., Franklin, L.D., He, J., Xu, D., May, G. and Stacey, G. (2010b) An integrated transcriptome atlas of the crop 
model Glycine max, and its use in comparative analyses in plants. The Plant Journal 63: 86-99.

[50] Lim, C.W., Lee, Y.W. and Hwang, C.H. (2011) Soybean nodule-enhanced CLE peptides in roots act as signals in GmNARK-mediated nodulation suppression. Plant Cell Physiol. 52: 1613-1627.

[51] Lin, M-H., Gresshoff, P.M., Indrasumunar, A., and Ferguson, B.J. (2011b) pHairyRed: a novel binary vector containing the DsRed2 reporter gene for visual selection of transgenic hairy roots. Molecular Plant 4: 537-545.

[52] Lin, Y-H., Ferguson, B.J., Kereszt, A. and Gresshoff, P.M. (2010) Suppression of hypernodulation in soybean by a leaf-extracted, NARK- and Nod factor-dependent small molecular fraction. New Phytologist 185: 1074-1086.

[53] Lin, Y-H., Lin, M-H., Gresshoff, P.M. and Ferguson, B.J. (2011a) An efficient petiolefeeding bioassay for introducing aqueous solutions into dicotyledonous plants. Nature Protocols 6: 36-45.

[54] Magori S, Oka-Kira E, Shibata S, Umehara Y, Kouchi H, Hase Y, Tanaka A, Sato S, Tabata S, Kawaguchi M (2009) TOO MUCH LOVE, a root regulator associated with the long-distance control of nodulation in Lotus japonicus. Molecular Plant-Microbe Interactions22: 259-268.

[55] Mahieu S, Fustec J, Faure M, Corree-Hellou G, Grozat Y (2007) Comparison of two ${ }^{15} \mathrm{~N}$ labeling methods for assessing nitrogen rhizodeposition of pea. Plant and Soil 295: 193-205.

[56] Mathews A, Carroll BJ, Gresshoff PM (1989) Development of Bradyrhizobium infection in supernodulating and non-nodulating mutants of soybean (Glycine max [L.] Merrill). Protoplasma150: 40-47.

[57] McNeill AM,Fillery IRP (2008) Field measurement of lupin belowground nitrogen accumulation and recovery in the subsequent cereal-soil system in a semi-arid Mediterranean-type climate. Plant and Soil 302: 297-316.

[58] Miyahara A, Hirani TA, Oakes M, Kereszt A, Kobe B, Djordjevic MA, Gresshoff PM (2008) Soybean nodule autoregulation receptor kinase phosphorylates two kinase-associated protein phosphatases in vitro. Journal of Biological Chemistry283: 2538125391.

[59] Miyazawa, H, Oka-Kira E, Sato N, Takahashi H, Wu GJ, Sato S, Hayashi M, Betsuyaku S, Nakazono M, Tabata S, Harada K, Sawa S, Fukuda H, Kawaguchi M (2010). The receptor-like kinase KLAVIER mediates systemic regulation of nodulation and nonsymbiotic shoot development in Lotus japonicus. Development 137: 4317-4325.

[60] Mortier V, Den Herder G, Whitford R, Van de Velde W, Rombauts S, D'haeseleer K, Holsters M, Goormachtig S (2010) CLE peptides control Medicago truncatula nodulation locally and systemically. Plant Physiology 153: 222-237. 
[61] Murphy AP (1991) Chemical removal of nitrate from water. Nature 350: 223-225.

[62] Newcombe W, Sippel D, Peterson RL (1979) The early morphogenesis of Glycine max and Pisumsativumroot nodules. Canadian Journal of Botany57: 2603-2616.

[63] Nishimura R, Ohmori M, Fujita H, Kawaguchi M (2002b) A Lotus basic leucine zipper protein with a RING-finger motif negatively regulates the developmental program of nodulation. Proceeding of the National Academy of Science USA 99: 1520615210.

[64] Okamoto S, Ohnishi E, Sato S, Takahashi H, Nakazono M, Tabata S, Kawaguchi M (2009) Nod factor/nitrate-induced CLE genes that drive HAR1-mediated systemic regulation of nodulation. Plant and Cell Physiology 50: 67-77.

[65] Peoples MB, Brockwell J, Herridge DF, Rochester IJ, Alves BJR, Urquiaga S, Boddey RM, Dakora FD, Bhattarai S, Maskey SL, Sampet C, Rerkasem B, Khans DF, Hauggaard-Nielsen H, Jensen BS (2009) The contributions of nitrogen-fixing crop legumes to the productivity of agricultural systems. Symbiosis 48: 1-17.

[66] Penmetsa RV, Uribe P, Anderson J, Lichtenzveig J, Gish JC, Nam YW, Engstrom E, Xu K, Sckisel G, Pereira M, Baek JM, Lopez- Meyer M, Long SR, Harrison MJ, Singh KB, Kiss GB, Cook DR (2008) The Medicago truncatula of the Arabidopsis EIN2 gene, sickle, is a negative regulator of symbiotic and pathogenic microbial interactions. The Plant Journal 55: 580-595.

[67] Postma JG, Jacobsen E, Feenstra WJ (1988) Three pea mutants with an altered nodulation studied by genetic-analysis and grafting. Journal of Plant Physiology132: 424430 .

[68] Reid, D.E., Ferguson, B.J., Hayashi, S., Lin, Y-H., Gresshoff, P.M. (2011a) Molecular mechanisms controlling legume autoregulation of nodulation. Annals of Botany 108: 789-795.

[69] Reid, D.E., Ferguson, B.J., Gresshoff, P.M. (2011b) NARK-dependent nodule regulation is activated in the shoot and root in response to inoculation and nitrate induced CLE peptides of soybean. Molecular Plant-Microbe Interactions 24: 606-618.

[70] Reid D.E., Hayashi S., Lorenc M., Stiller J., Edwards D., Gresshoff P.M., Ferguson B.J. (2012) Identification of systemic responses in soybean nodulation by xylem sap feeding and complete transcriptome sequencing reveal a novel component of the autoregulation pathway. Plant Biotechnology Journal 10: 680-689.

[71] Rispail N, Kalo P, Kiss GB, Ellis THN, Gallardo K, Thompson RD, Prats E, Larrainzar E, Ladrera R, González EM, Arrese-Igor C, Ferguson BJ, Gresshoff PM, Rubiales D (2010) Model legumes contribute to faba bean breeding. Field Crops Research 115: 253-269.

[72] Rockstrøm J, Steffen W, Noone K, Persson A, Chapin III FS, Lambin EF, Lenton TM, Scheffer M, Folke C, Schellnhuber HJ, Nykvist B, de Wit CA, Hughes T, van der 
Leeuw S, Rodhe H, Sörlin S, Snyder PK, Costanza R, Svedin U, Falkenmark M, Karlberg L, Corell RW, Fabry VJ, Hansen J, Walker B, Liverman D, Richardson K, Crutzen P, Foley JA (2009) A safe operating space for humanity. Nature 461: 472-475.

[73] Salvagiotti F, Cassman KG, Specht JE, Walters DT, Weiss A, Dobermann A (2008) Nitrogen uptake, fixation and response to fertilizer $\mathrm{N}$ in soybeans: A review. Field Crops Research 108: 1-13.

[74] Schmutz, J., Cannon, S.B., Schlueter, J., Ma, J., Mitros, T., Nelson, W., Hyten, D.L., Song, Q., Thelen, J.J., Cheng, J., Xu, D., Hellsten, U., May, G.D., Yu, Y., Sakurai, T., Umezawa, T., Bhattacharyya, M.K., Sandhu, D., Valliyodan, B., Lindquist, E., Peto, M., Grant, D., Shu, S., Goodstein, D., Barry, K., Futrell-Griggs, M., Abernathy, B., Du, J., Tian, Z., Zhu, L., Gill, N., Joshi, T., Libault, M., Sethuraman, A., Zhang, X.C., Shinozaki, K., Nguyen, H.T., Wing, R.A., Cregan, P., Specht, J., Grimwood, J., Rokhsar, D., Stacey, G., Shoemaker, R.C., Jackson, S.A. (2010) Genome sequence of the palaeopolyploid soybean. Nature 463: 178-183.

[75] Scott P, Pregelj L, Chen N, Hadler J, Djordjevic M, Gresshoff P (2008). Pongamia pinnata: An untapped resource for the biofuels industry of the future. Bio Energy Research 1: 2-11

[76] Searle, I.R., Men, A.E., Laniya, T.S., Buzas, D.M., Iturbe-Ormaetxe, I., Carroll, B.J. and Gresshoff, P.M. (2003) Long-distance signaling in nodulation directed by a CLAVATA1-like receptor kinase. Science 299: 109-112.

[77] Severin, A.J.,Woody, J.L., Bolon, Y.T., Joseph, B., Diers, B.W., Farmer, A.D., Muehlbauer, G.J., Nelson, R.T., Grant, D., Specht, J.E., Graham, M.A., Cannon, S.B., May, G.D., Vance, and Shoemaker, R.C. (2010) RNA-seq atlas of Glycine max: A guide to the soybean transcriptome. BMC Plant Biology 10: 160.

[78] Sutton MA, Oenema O, Erisman JW, Leip A, van Grinsven H, et al. (2011) Too much of a good thing. Nature 472: 159-162.

[79] Turgeon BG, Bauer WD (1982) Early events in the infection of soybean by Rhizobium japonicum. Time course and cytology of the initial infection process. Canadian Journal of Botany60: 152-161.

[80] Turgeon BG, Bauer WD (1985) Ultrastructure of infection thread development during infection of soybean by Rhizobium japonicum. Planta163: 328-349.

[81] Udvardi M, Day D (1997) Metabolite transport across symbiotic membranes of legume nodules. Annual Review of Plant Physiology and Plant Molecular Biology 48: 493-523.

[82] Vance CP (2001) Symbiotic nitrogen fixation and phosphorus acquisition.Plant nutrition in a world of declining renewable resources. Plant Physiology 127: 390-397.

[83] Vernie T, Moreau S, de Billy F, Plet J, Combier JP, Rogers C, Oldroyd G, Frugier F, Niebel A, Gamas P (2008) EFD Is an ERF transcription factor involved in the control 
of nodule number and differentiation in Medicago truncatula. The Plant Cell20: 26962713.

[84] Yao PJ, Vincent JM (1969) Host specificity in the root "curling factor" of rhizobium spp. Australian Journal of Biological Science 22: 413-423.

[85] Zhang C, Ghabrial SA (2006) Development of Bean pod mottle virus-based vectors for stable protein expression and sequence-specific virus-induced gene silencing in soybean. Virology 344: 401-411. 
